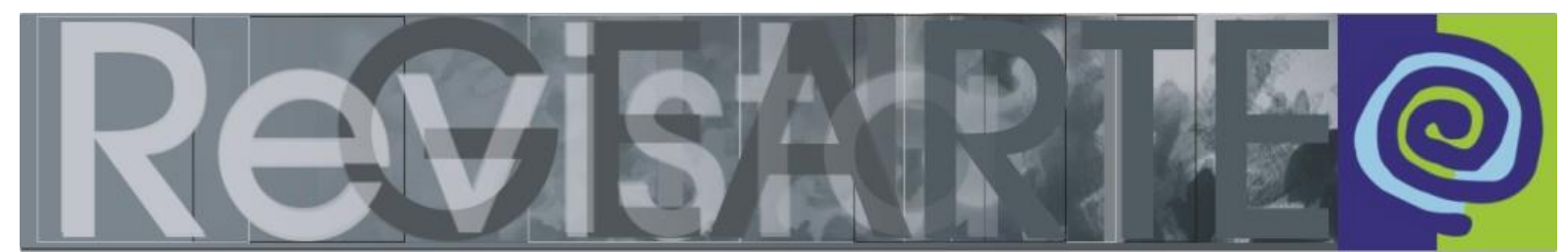

ISSN 2357-9854 | e-ISSN 2596-3198 (online)

\title{
A arte e a cultura afro-brasileira como descentramento sensorial na Pedagogia
}

\author{
Francione Oliveira Carvalho \\ (Universidade Federal de Juiz de Fora — UFJF Juiz de Fora/MG, Brasil)
}

\begin{abstract}
RESUMO - A arte e a cultura afro-brasileira como descentramento sensorial na Pedagogia - O artigo discute como a disciplina Arte e Cultura Afro-Brasileira, oferecida no curso de Pedagogia da UFJF, pode desencadear processos significativos que ajudem as/os estudantes a construir novos conhecimentos sobre a arte e o seu ensino. Para isso divide o texto em quatro eixos: 1 . A cidade como disparadora de memórias, saberes e experiências; 2. Explorando novos Territórios Educativos; 3. Experiências estéticas-pedagógicas; 4. Processos compartilhados de criação. Aponta que partir de diálogos interdisciplinares e da cultura afro-brasileira pode-se ampliar os atravessamentos sensoriais e perceptivos à que as/os estudantes da Pedagogia são expostas, provocando aquilo que Le Breton (2016) chama de "descentramento sensorial". Uma maneira de desapegar-se das familiaridades perceptivas para recapturar outras maneiras de "sentir a multidão dos mundos que se escoram no mundo".
\end{abstract}

PALAVRAS-CHAVE

Pedagogia. Arte e cultura afro-brasileira. Ensino de Arte. Percepção.

ABSTRACT - Afro-Brazilian art and culture as sensory decentering in Pedagogy - The article discusses how the discipline of Afro-Brazilian Art and Culture, offered in the Pedagogy course at the Federal University of Juiz de For a (Brazil), can trigger significant processes that help students to build new knowledge about art and its teaching. To achieve this, the paper is divided into four axes: 1. The city as a trigger for memories, knowledge and experiences; 2. Exploring new Educational Territories; 3. Aesthetic-pedagogical experiences; 4. Shared creation processes. The paper points out that starting from interdisciplinary dialogues and Afro-Brazilian culture, the sensory and perceptual crossings to which Pedagogy students are exposed can be expanded, causing what Le Breton (2016) calls "sensory decentering". A way of detaching from perceptual familiarities to recapture other ways of "feeling the multitude of worlds that support the world".

\section{KEYWORDS}

Pedagogy. Afro-Brazilian art and culture. Teaching of Art. Perception.

\begin{abstract}
RESUMEN - El arte y la cultura afrobrasileña como descentramiento sensorial en la Pedagogía - El artículo discute cómo la disciplina de Arte y Cultura Afrobrasileña, impartida en el curso de Pedagogía de la Universidad Federal de Jueces de For a (Brasil), puede desencadenar procesos significativos que ayuden a los estudiantes a construir nuevos conocimientos sobre el arte y su enseñanza. Para lograrlo, el trabajo se divide en cuatro ejes: 1. La ciudad como detonante de memorias, conocimientos y vivencias; 2. Explorar nuevos territorios educativos; 3 . Experiencias estético-pedagógicas; 4. Procesos de creación compartida. El artículo señala que a partir de los diálogos interdisciplinarios y la cultura afrobrasileña, los cruces sensoriales y perceptuales a los que están expuestos los estudiantes de pedagogía se pueden ampliar, provocando lo que Le Breton (2016) denomina "descentramiento sensorial". Una forma de desprenderse de las familiaridades perceptivas para recuperar otras formas de "sentir la multitud de mundos que sostienen el mundo".

PALABRAS CLAVE
\end{abstract}

Pedagogía. Arte y cultura afrobrasileña. Enseñanza del Arte. Percepción.

CARVALHO, Francione Oliveira. A arte e a cultura afro-brasileira como descentramento sensorial na Pedagogia. 394

Revista GEARTE, Porto Alegre, v. 8, n. 2, p. 394-414, maio/ago. 2021.

http://dx.doi.org/10.22456/2357-9854.117510 


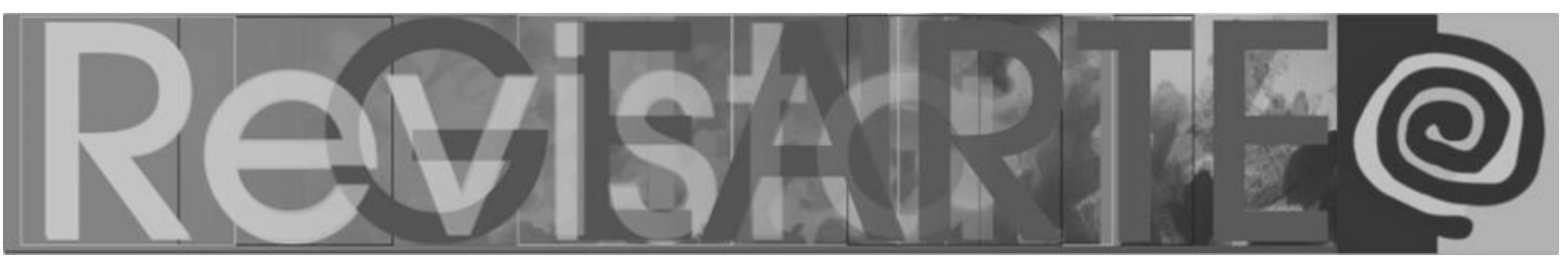

Atuar na formação inicial de professores é uma tarefa complexa, ainda mais complexificada na pedagogia. Se em outras licenciaturas os estudantes terão, geralmente, quatro anos para aprofundamento em sua área de formação atrelada às questões pedagógicas, na pedagogia, o período de formação perpassa tantos campos de conhecimento - e pretendem tantos objetivos diferentes - que nem sempre é possível identificar, nos currículos, qual seria a centralidade específica da formação do pedagogo. Essa indefinição pode ser percebida ao olharmos atentamente para alguns projetos de cursos disponíveis no país. Entretanto, espera-se que, ao término da graduação, os egressos estejam preparados para atuar no Ensino Infantil, nos anos iniciais do Ensino Fundamental, com foco na alfabetização, na supervisão e na gestão escolar e que possam, ainda, atuar nas diferentes áreas de conhecimento presentes no currículo do primeiro ciclo do Ensino Fundamental.

Por mais que as questões relativas aos processos de ensino-aprendizagem perpassem todas essas dimensões e enfoques, cada uma delas exige um olhar atento, assim como metodologias próprias que carecem de maior aprofundamento nos cursos. Na grande maioria das licenciaturas em pedagogia oferecidas no Brasil, inclusive a da Universidade Federal de Juiz de Fora, lugar de onde falo e atuo, há apenas uma disciplina obrigatória que discute as questões relacionadas ao ensino da arte. Dessa forma, como desencadear processos significativos que ajudem os estudantes a construir novos conhecimentos sobre a arte e o seu ensino? Como garantir conhecimentos e repertórios suficientes para que os pedagogos possam atuar como mediadores da arte? Como promover uma ressignificação da cultura a partir de experiências diversas e sensíveis? Como assegurar que essas experiências impactarão na formação e na atuação profissional dos egressos da pedagogia?

$\mathrm{Na}$ expectativa de ampliar a vivência dos estudantes com a dimensão do estético e do sensível e, também, de garantir uma maior presença da arte no currículo da Licenciatura em Pedagogia da UFJF, os docentes responsáveis pela área oferecem, a cada semestre, disciplinas eletivas diversas, que transitam $\mathrm{e}$

CARVALHO, Francione Oliveira. A arte e a cultura afro-brasileira como descentramento sensorial na Pedagogia. 395 Revista GEARTE, Porto Alegre, v. 8, n. 2, p. 394-414, maio/ago. 2021.

Disponível em: http://seer.ufrgs.br/gearte 


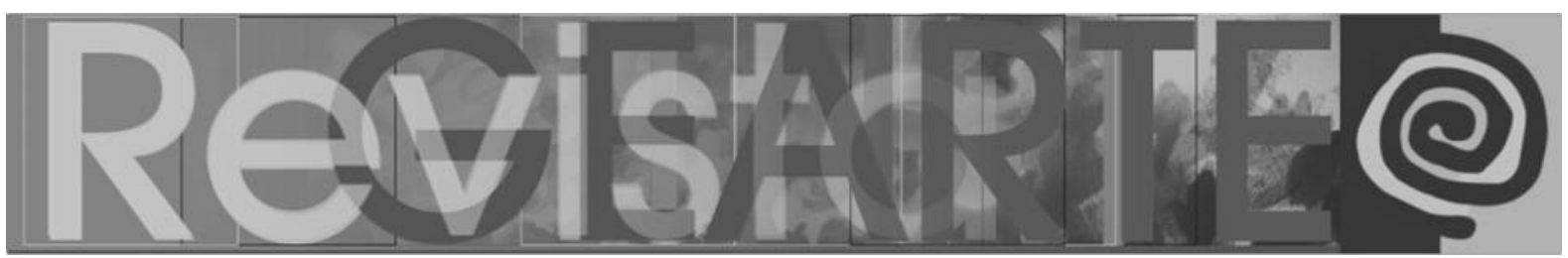

exploram diferentes perspectivas da arte e da cultura. Dessa forma, neste texto, irei me concentrar numa dessas disciplinas, a eletiva Arte e Cultura Afro-Brasileira, oferecida ao menos uma vez ao ano às licenciaturas de Pedagogia, Artes Visuais e História da UFJF.

Estender a disciplina para outros cursos de formação docente, e não exclusivamente à pedagogia, é uma ação metodológica. Ao inserir estudantes de experiências e trajetórias diferentes para refletir sobre temas complexos e, por si só, interdisciplinares, tais como corpo, cultura, raça, memória, acervos e patrimônio, espera-se estimular a troca de saberes, a ampliação de horizontes e a construção colaborativa de conhecimentos. Além disso, a proposta visa minimizar uma situação, muitas vezes, recorrente na licenciatura em pedagogia: a não circulação dentro da própria universidade. Enquanto os licenciandos e as licenciandas de outras áreas da UFJF possuem o hábito de cursarem uma parte das disciplinas eletivas em diferentes unidades acadêmicas, aproximando e aprofundando conhecimentos específicos a partir de seus interesses, na Pedagogia, poucos saem do território da Faculdade de Educação. Assim, cursar disciplinas com estudantes que trazem outras experiências é algo renovador e estimulante tanto para os estudantes quanto para o professor.

O objetivo da disciplina Arte e Cultura Afro-brasileira é discutir o conceito de cultura afro-brasileira e a sua relação tanto com a ancestralidade e os valores civilizatórios de matriz africana quanto com as questões étnico-raciais brasileiras. Compreendendo raça como construção social e política permeada por relações de poder que marcam a experiência dos sujeitos. A disciplina objetiva, ainda, valorizar e problematizar a presença negra no Brasil, a partir de suas riquezas culturais, artísticas e filosóficas, dando destaque para as produções contemporâneas de diversas áreas, tais como as artes visuais, as artes cênicas, a literatura e o cinema, pretendendo contribuir para a consolidação das leis 10.639/03 e 11.645/08, ao mesmo tempo em que acessa e gera produção de novos conhecimentos educativos sobre a temática. 


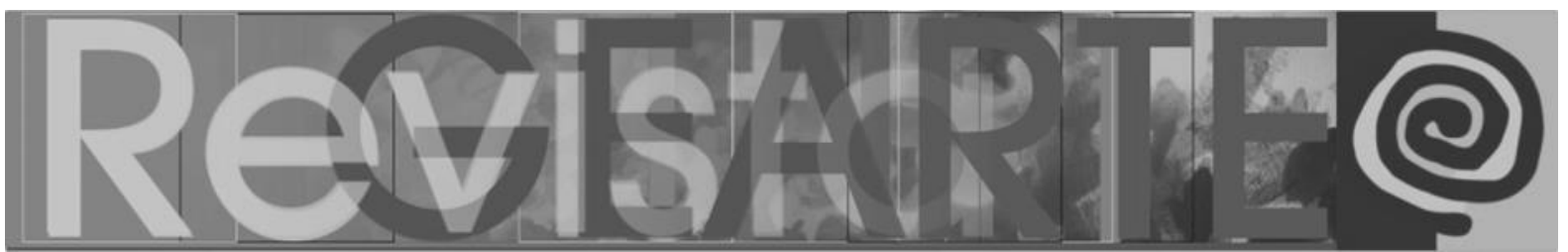

A cada novo oferecimento da disciplina há um enfoque específico que centraliza todo o trabalho teórico-prático a ser vivenciado no semestre, tal como a corporeidade negra, a memória e o patrimônio, as visualidades diaspóricas e as epistemologias negras. Aqui, trago experiências diversas, que, em menor ou maior profundidade, foram vivenciadas nas diversas edições da disciplina, tendo como base as imagens, os sons, os movimentos e os textos.

\section{A cidade como Disparadora de Memórias, Saberes e Experiências}

Figura 1 - Trabalho de campo no centro de Juiz de Fora

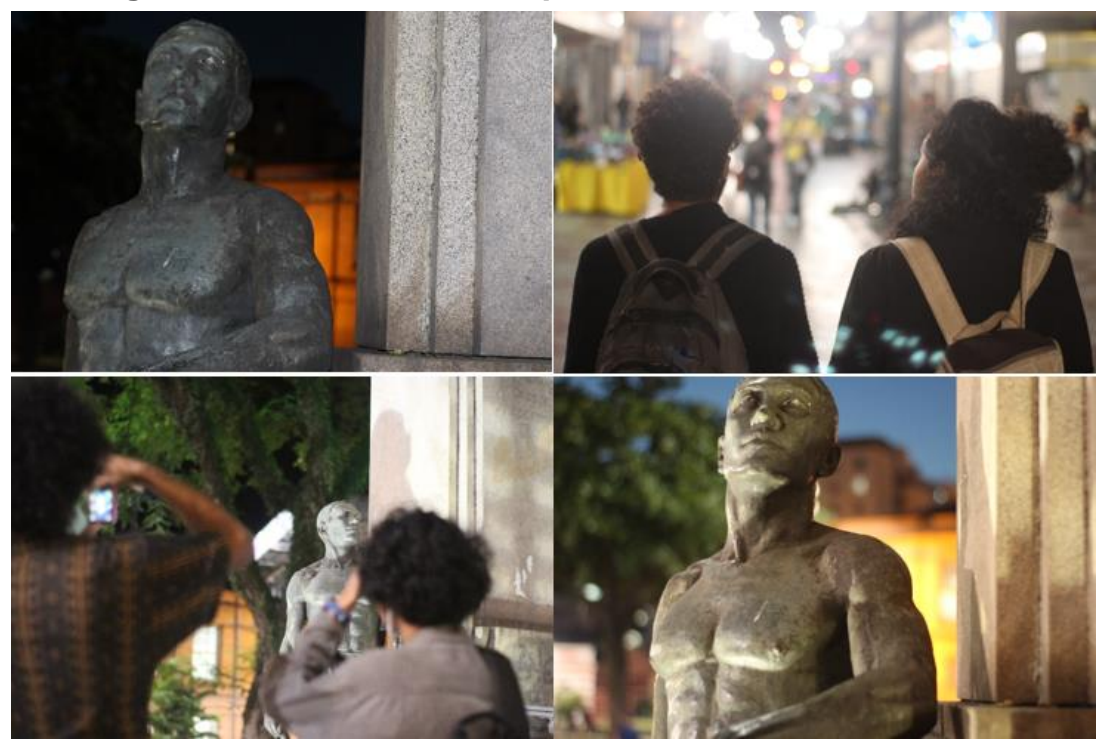

Fonte: Acervo do autor (2017).

É necessário reconhecermos que as cidades exercem funções pedagógicas para além de suas tarefas econômicas, sociais e políticas tradicionais. Nessa perspectiva, elas compõem redes de possibilidades educativas que as recolocam na relação com os outros espaços de educação, tal como a escola e a universidade. O conceito de comunidade de aprendizagem, assim como o de cidade educadora, ampliam nossa compreensão de educação e de formação de professores, pois reinventam a escola e a cidade e, nelas, consequentemente, a comunidade como lugar de convivência, de diálogo e de aprendizagens permanentes, reconhecendo a diversidade cultural e artística dos centros urbanos como centrais na mediação cultural e afirmação da cidadania. 


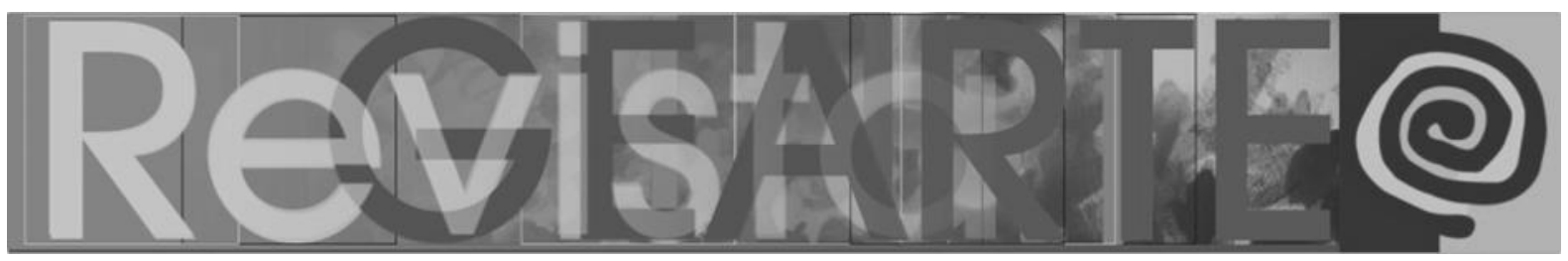

Partindo dessa ideia, os estudantes são convidados a fazer um exercício etnográfico coletivo no centro da cidade, acompanhados pelo professor. Apoiandose em alguns procedimentos da etnografia urbana, os estudantes realizam observações, registros fotográficos, audiovisuais e sondagens com transeuntes que os ajudem a perceber a dinâmica espacial, cultural e humana do território vivenciado com destaque para as questões étnico-raciais.

A cidade de Juiz de Fora, situada à distância de 283 km de Belo Horizonte, capital do estado de Minas Gerais, foi fundada em 1850. Este período corresponde ao final do Ciclo do Ouro e ao início da expansão cafeeira, movida pelo trabalho escravo de negros e crioulos que, naquela época, correspondiam a mais de $60 \%$ da população local. A cidade nasceu no mesmo ano do fim do tráfico de escravos. A proibição, no entanto, não arrefeceu o comércio humano para o trabalho forçado. Assim, Juiz de Fora tornou-se um importante entreposto comercial de escravos, dada a sua proximidade com a corte imperial instalada na cidade do Rio de Janeiro. Com a derrocada final do comércio escravo em 1888 e a chegada dos imigrantes europeus para o trabalho nas grandes lavouras de café, a cidade viveu o seu auge econômico entre o final do século XIX até 1929, devido a uma rápida industrialização e consolidação de um sistema financeiro-bancário de forte impacto não só na região, mas em todo o estado de Minas Gerais. A grave crise econômica vivenciada em todo o mundo após a queda da Bolsa de Valores de Nova York fez com que a cidade precisasse se reinventar e diversificar sua economia - estratégia que marca Juiz de Fora na contemporaneidade. Com quase 600 mil habitantes, a cidade é movida economicamente pela prestação de serviços, tendo, nesse contexto, a Universidade Federal de Juiz de Fora, fundada em 1960, cumpre um importante papel, seguida das atividades industriais e agrícolas.

Esse pequeno recorte da história de Juiz de Fora é importante para que possamos compreender as questões trazidas pelos estudantes após vivenciarem o percurso pelo centro da cidade e para que possamos entender, também, como a urbanização da cidade revela escolhas e apagamentos. Uma cidade é composta por memórias sobrepostas que desvendam relações de força, conflitos, imagens e 


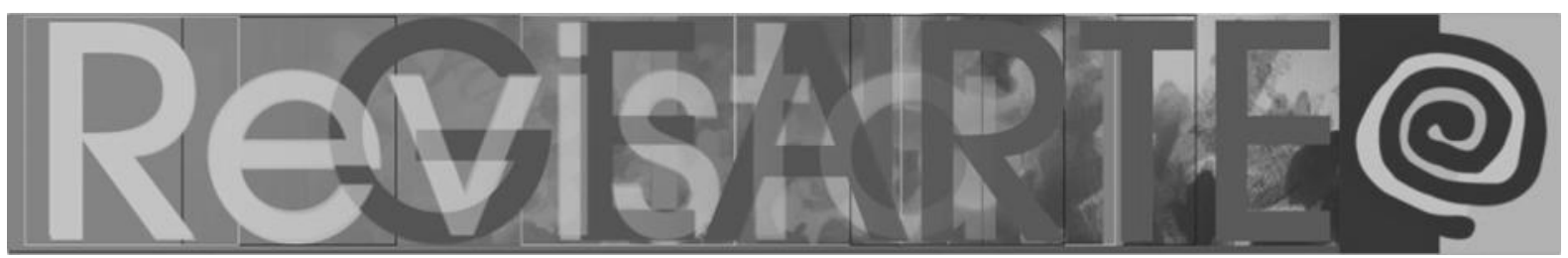

institucionalizações de narrativas. Portanto, o trajeto percorrido pelos alunos e pelas alunas indicam uma construção de memória local que não pode ser encarada como única, porque muitas são as experiências e as subjetividades não contempladas e reconhecidas.

O trabalho de campo foi iniciado na Praça Antônio Carlos Ribeiro de Andrada, nome de um importante político nascido em Barbacena - cidade próxima de Juiz de Fora - que atuou em diversos cargos, tanto estaduais quanto federais. $\mathrm{Na}$ praça, há o imponente prédio da antiga fábrica de tecidos Bernardo Mascarenhas, que é, hoje, um centro cultural. O percurso contemplou, ainda, a Praça João Penido, cujo nome é de um político local do século XIX. Ela é conhecida pela população como Praça da Estação, devido à Estrada de Ferro Dom Pedro II, construída em 1875. É ali que se inicia a rua mais importante e popular da cidade, a Halfeld, batizada em homenagem ao engenheiro alemão Heinrich Willhelm Ferdinand Halfeld (1797-1873).

A Rua Halfeld possui muitas lojas, bares e serviços, tornando-se, por isso, um dos locais mais disputados para os vendedores ambulantes e para o comércio de rua. Ela abriga, ainda, o mais importante teatro da cidade, o Cine-Theatro Central, construído no estilo Art Déco e inaugurado em 1929; bem como o Museu do Crédito Real, de estilo eclético, onde também predominam traços Art Déco; o antigo prédio do Paço Municipal, inspirado na arquitetura neoclássica, e o Parque Halfeld, que segue a mesma tendência arquitetônica em seus chafarizes, placas, monumentos e bustos de membros da família Halfeld e de políticos históricos da cidade.

É importante registrar que, ao longo do percurso de $3 \mathrm{~km}$, as duas referências da presença negra na cidade se dão a partir de duas esculturas, em bronze, de negros escravizados com ferramentas de trabalho. Constata-se, também, a ausência de referências aos grupos indígenas que habitavam a região antes da chegada dos portugueses no Brasil, além do silenciamento a respeito do envolvimento das mulheres na história local. 


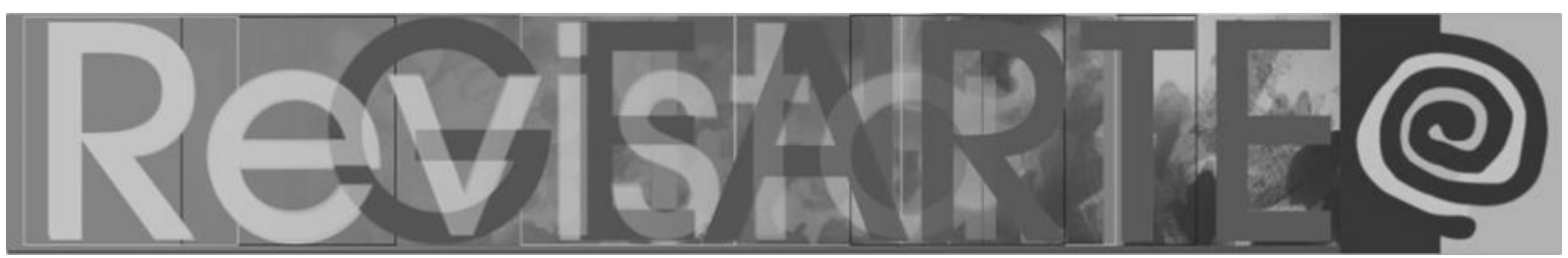

A urbanização e o planejamento das cidades, a arte urbana, os diálogos culturais, o patrimônio e a mediação cultural, assim como a invisibilidade das questões étnicas e de gênero centralizam tanto o estudo de campo quanto os trabalhos que partem dele, como a criação de percursos pedagógicos, de obras artísticas e de projetos de intervenções urbanas. As produções realizadas ao longo das diversas edições da disciplina discutem os conflitos e as experiências vivenciadas na cidade e nos ajudam a refletir sobre a utilização do espaço urbano $\mathrm{e}$ as formas de potencializar seu uso. Elas são diferentes materialidades e processos de criação que ajudam a perceber como os futuros professores se relacionam com o território onde vivem e quais são os possíveis impactos dessa relação em suas investigações pedagógicas e artísticas.

\section{Explorando Novos Territórios Educativos}

Além dos percursos etnográficos na cidade de Juiz de Fora, em cada edição da disciplina são realizadas viagens para outras cidades brasileiras, que possibilitam perceber como a cultura afrodescendente se perpetua em tradições, memórias e nos acervos das instituições culturais. Os estudantes já tiveram a oportunidade de visitar o Instituto Inhotim, em Brumadinho, Minas Gerais; a exposição Histórias Afro-Atlânticas no MASP e o Museu Afro Brasil, ambos na cidade de São Paulo; e, ainda, conhecer, na cidade do Rio de Janeiro, o Museu de Arte do Rio de Janeiro, o Instituto de Pesquisas e Memória Pretos Novos e a Gamboa, região portuária, batizada pelo pintor Heitor dos Prazeres como Pequena África. 


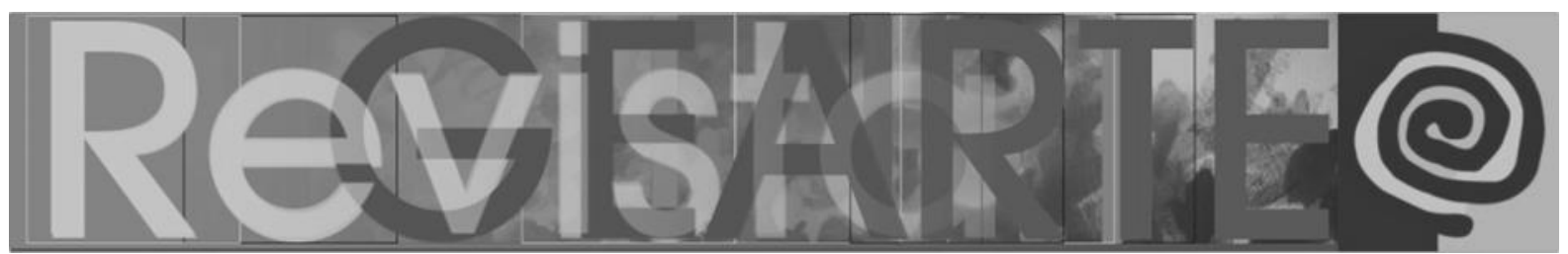

Figura 2 - Registros de saídas no Programa Territórios Educativos

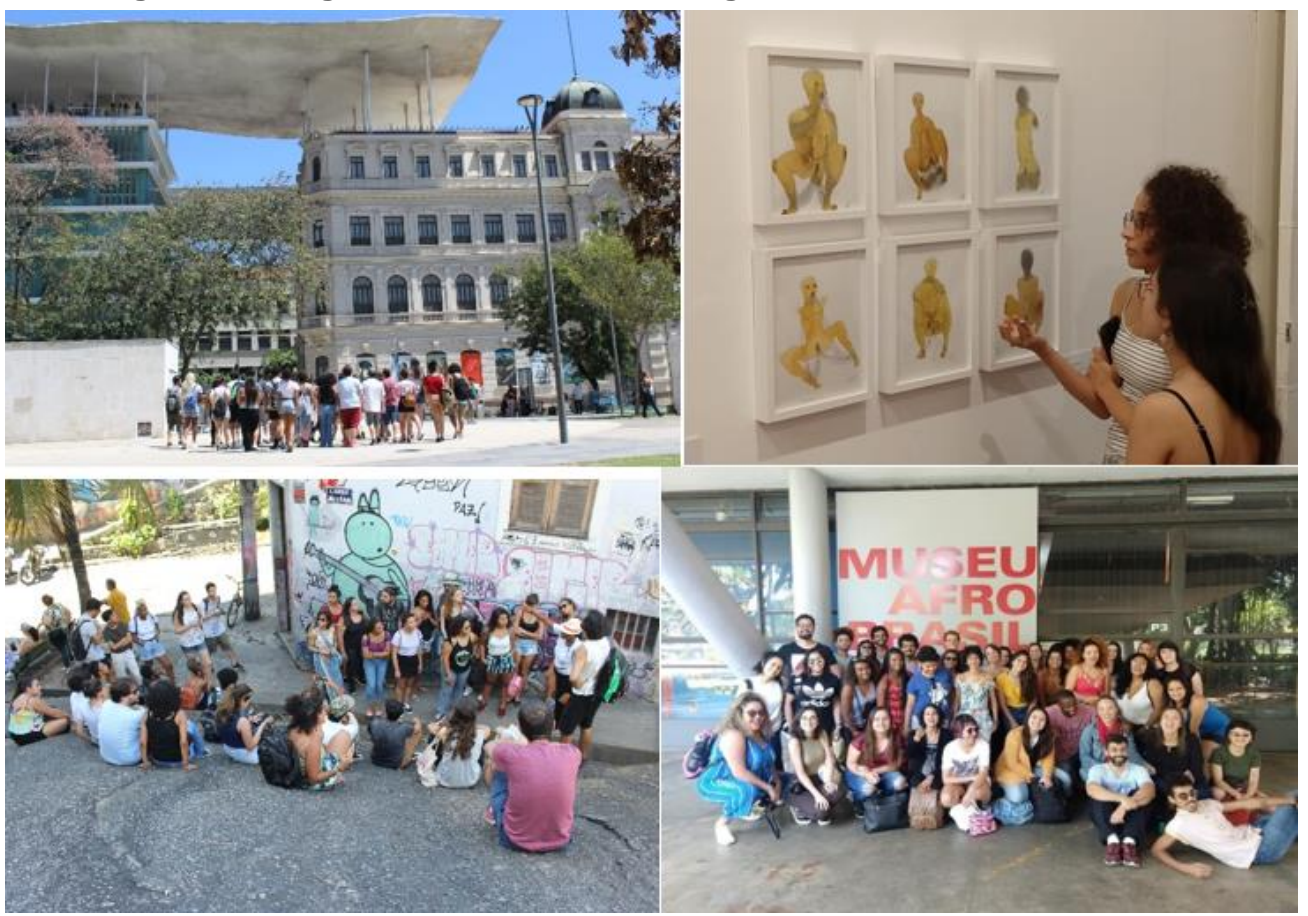

Fonte: Acervo do autor (2019).

Explorar novos territórios é abrir-se a outras culturas sensoriais, a outras maneiras de sentir o mundo. A experiência do viajante, como afirma Le Breton "[...] é geralmente a do despovoamento de seus sentidos, ele é confrontado com sabores inesperados, com odores, músicas, ritmos, sons, contatos e usos do olhar que sacodem suas antigas rotinas e lhe ensinam a sentir outramente sua relação com o mundo e com os outros" (LE BRETON, 2016, p. 18). Essa abertura perceptiva para as coisas é fundamental no trabalho docente, pois a cotidianidade do trabalho pedagógico exige que renovemos constantemente nossas práticas e fazeres, que tenhamos a capacidade de desapegar das "[...] familiaridades perceptivas para recapturar outras modalidades de sentir a multidão dos mundos" (LE BRETON, 2016, p. 19).

Planejar expedições culturais com estudantes, seja na escola ou na universidade, não é uma tarefa simples, como nos apontam Martins e Picosque (2012), pois existem questões pedagógicas, financeiras e institucionais que precisam ser consideradas e providenciadas. 


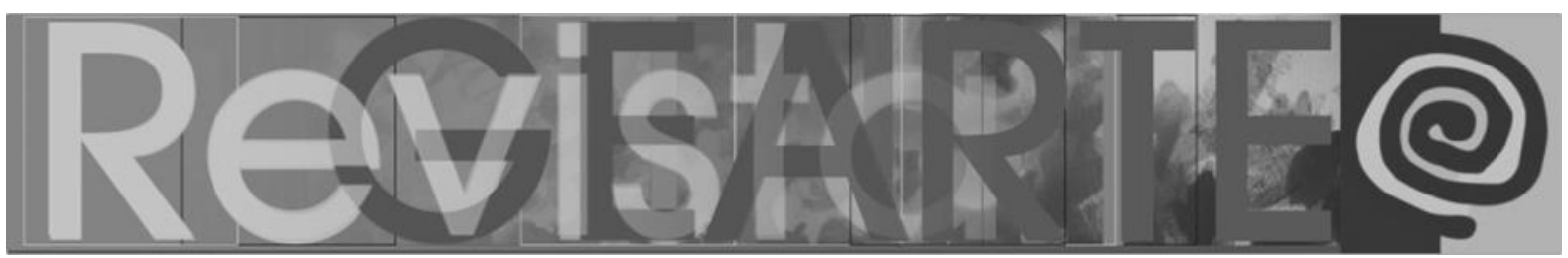

O conceito de expedição e de suas equipes viajantes se torna também uma boa preparação para a própria visita/expedição. Compreender as tarefas de cada equipe pode ampliar a possibilidade de ler a viagem/expedição com olhares focados, atentos, sensíveis, diversos [...]. (MARTINS; PICOSQUE, 2012, p. 53)

No caso da UFJF, a efetivação das viagens ocorre a partir do Programa Territórios Educativos, promovido pela Pró-reitoria de Graduação da Universidade Federal de Juiz de Fora - PROGRAD. A cada início de semestre, há um edital específico para a efetivação de atividades em ambiente externo ao campus, dentro ou fora do estado de Minas Gerais. Para concorrer às vagas, os professores encaminham um projeto pedagógico que detalha o planejamento de todas as ações e seus deslocamentos. Ao retornar da expedição, os responsáveis precisam entregar relatórios de avaliação e de reflexão sobre a experiência vivenciada no coletivo.

\begin{abstract}
As atividades desenvolvidas em diferentes espaços formativos são fundamentais para o desenvolvimento profissional de estudantes em diferentes formações da Graduação. O mundo contemporâneo é constituído por aceleradas mudanças trazidas pelo meio técnico, científico e informacional. Dessa forma, a possibilidade formativa trazida pelas viagens técnicas, trabalhos de campos e outras imersões a diferentes territórios educativos configura-se em importante estratégia de formação teórica, prática e cidadã. (UNIVERSIDADE FEDERAL DE JUIZ DE FORA, 2020)
\end{abstract}

Após cada expedição, os alunos e alunas apresentam, em sala de aula, um recorte de suas observações, seus registros em áudio e vídeo, bem como suas anotações e reflexões para serem problematizadas a partir da experiência vivenciada. Questões previamente levantadas sobre o percurso visitado e suas relações com as discussões e vivencias em sala também são acionadas. Não há um formato único para a socialização. Algumas vezes os resultados surgem em pequenos filmes documentais, vídeos, suportes visuais diversos ou montagem em Power Point com fotografias e áudios. Os registros revelam muitas questões em comum:

- A importância da experiência coletiva na formação dos estudantes, pois muitos têm, naquele momento, a primeira oportunidade de viajar 


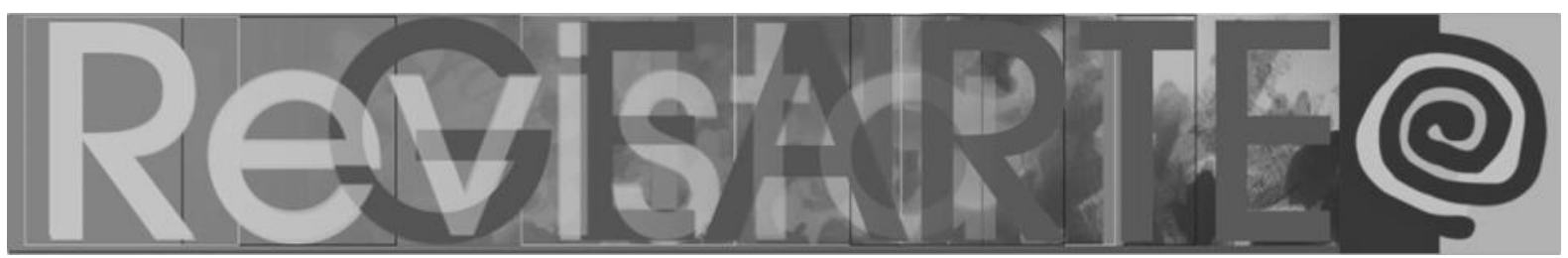

juntos, conhecer as cidades, suas instituições e suas práticas culturais. Além de que novos vínculos, entre professores e alunos e entre alunos de cursos diferentes, são formados.

- A troca de experiências e a ampliação das referências entre os estudantes nas exposições visitadas é efetiva. Estudantes de áreas diferentes, com predomínio das artes visuais, pedagogia e história, tornam-se mediadores entre si, construindo, juntos, sentidos para o que vivenciam.

- A constatação do distanciamento da memória, que é revelada pelo patrimônio artístico-cultural com o cotidiano das pessoas, o que provoca um não-pertencimento dos moradores com o território onde vivem. As entrevistas com os transeuntes nos diversos territórios revelaram que as pessoas não sabem quem são os retratados nos monumentos, as personalidades que dão nome as ruas, os logradouros públicos e suas relações com a história da cidade.

- O território da cidade, enquanto espaço subjetivo, dialoga com o tempo e o espaço, criando regras invisíveis (porém presentes); o olhar atento para ações efêmeras e marcas visuais são produzidas por artistas, ativistas ou anônimos que renovam o espaço urbano.

- A relação conflituosa entre a paisagem natural e a paisagem urbana.

\section{Experiências Estéticas-pedagógicas}

Para Ana Mae Barbosa (1998), a experiência, para ser plena, precisa ter qualidade estética. É ela que unificará a experiência enquanto reflexão e emoção. Tendo como base os estudos realizados a partir da obra de John Dewey, ela afirma que:

Qualidade estética não é apenas o reconhecimento descolorido e frio daquilo que foi feito, mas uma condição receptiva interna, que é a válvula propulsora de futuras experiências. A qualidade estética de uma 


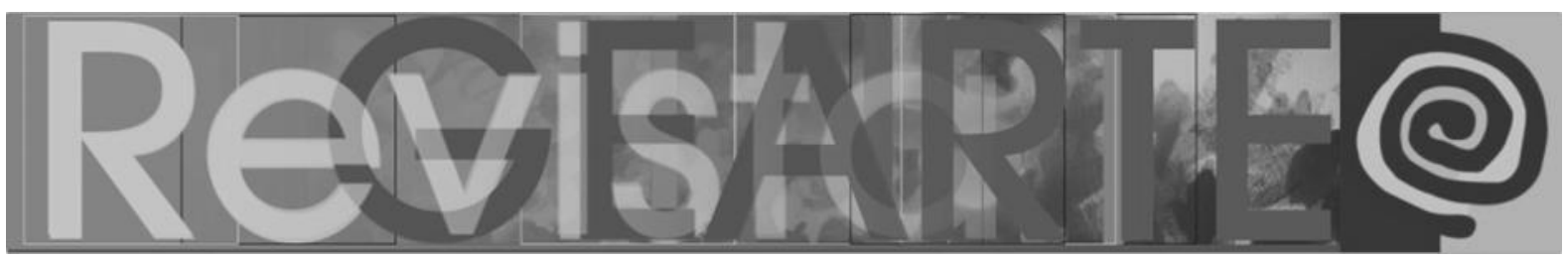

experiência de qualquer natureza é a culminação de um processo. (BARBOSA, 1998, p. 22)

Levando em consideração a compreensão de qualidade estética descrita pela autora, ao longo da disciplina, foram criadas oportunidades nas aulas, para que experiências estéticas significativas fossem promovidas. Na edição de 2018 tivemos aula na Galeria Guaçuí, localizada no Instituto de Artes e Design da UFJF. Naquele momento estava em exibição a exposição Preto ao Cubo, mostra que reuniu obras de 24 artistas/estudantes da instituição, muitos deles matriculados na disciplina naquele momento. Inclusive, Karina Pereira, uma das curadoras da exposição e mediadora da experiência.

As obras tratavam dos mais diversos temas que perpassam às experiências de negritude vivenciadas no Brasil e apontavam temáticas caras aos jovens criadores afrodescendentes no país, tais como as questões de gênero e sexualidade, colorismo, colonialidade, genocídio da juventude negra brasileira e representatividade. As obras traziam uma variedade de abordagens, que refletiam também numa variedade de poéticas e procedimentos artísticos, tais como a pintura, a escultura, a performance, a instalação, a videoarte, o lambe-lambe, o graffiti e a fotografia. 


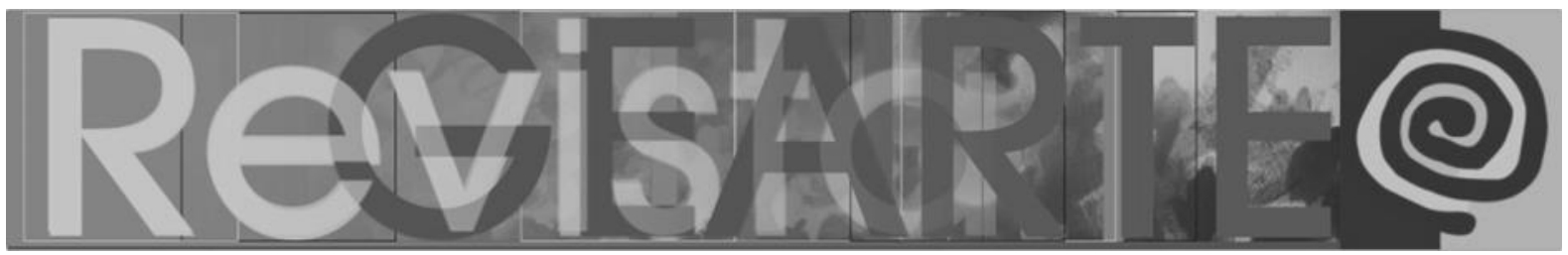

Figura 3 - Estudantes visitam a exposição Preto ao Cubo, no Instituto de Artes e Design da UFJF

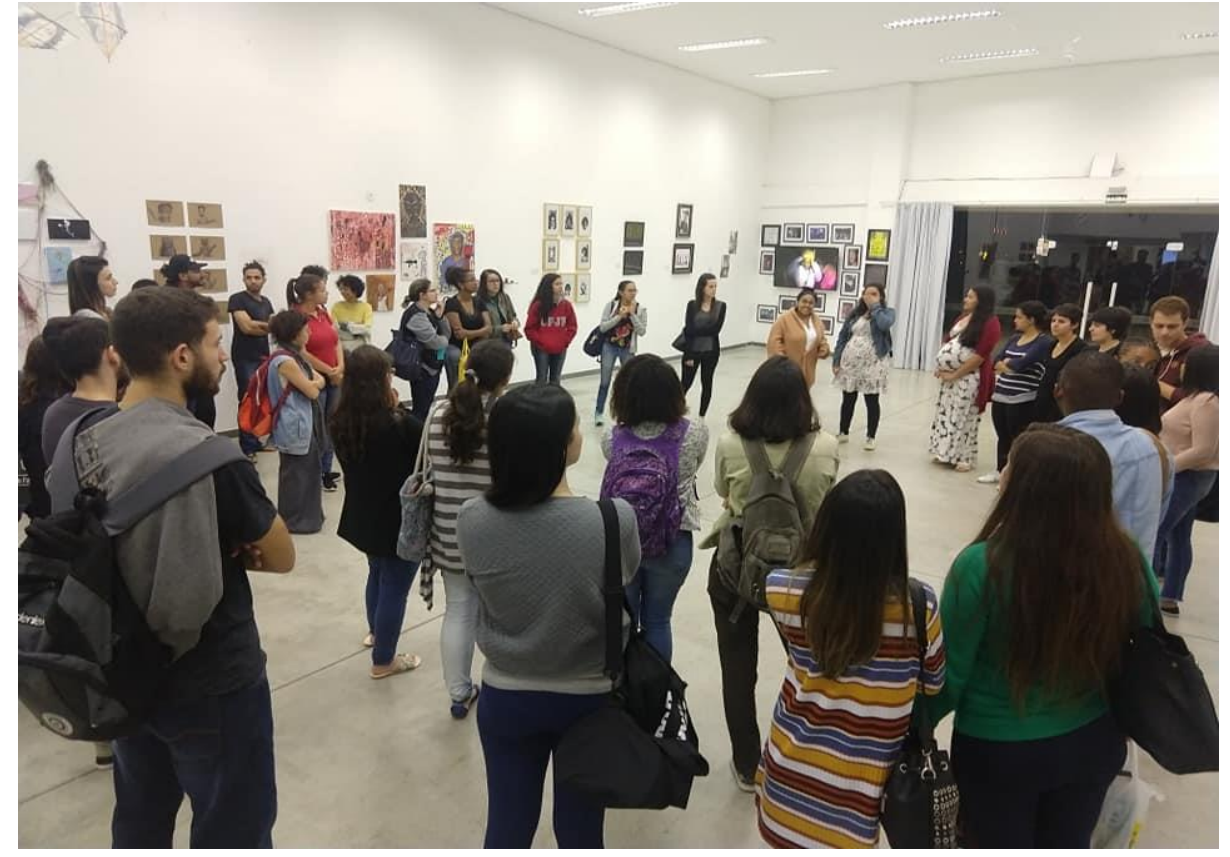

Fonte: Acervo do autor (2018).

Ao longo do encontro as vozes dos artistas, da curadora e dos outros estudantes, trançaram-se novas tramas de diálogos, de compartilhamentos e de conhecimentos. Os artistas, figuras às vezes romantizadas e idealizadas, tornavam-se de carne e osso, e melhor ainda, eram parte do grupo. Principalmente, no caso dos licenciados em pedagogia, pouco familiarizados com o circuito profissional da arte. Essa foi uma possibilidade de acessar diferentes códigos artísticos e poéticos, como tirar dúvidas que englobam questões desde o processo de criação até o processo de montagem e preservação das obras.

Em outra edição da disciplina, no módulo centrado nas questões da corporeidade negra, tivemos a colaboração da artista, educadora e pesquisadora Thalita Reis, que, até o momento, havia participado do curso como ouvinte. Graduada e Mestre em Dança, com extensa experiência profissional como bailarina e professora tanto no Ensino Básico quanto universitário, Thalita Reis propôs desenvolver uma experiência estética-pedagógica com a turma, centrada na corporeidade negra que dialogasse com os textos e discussões teóricas 


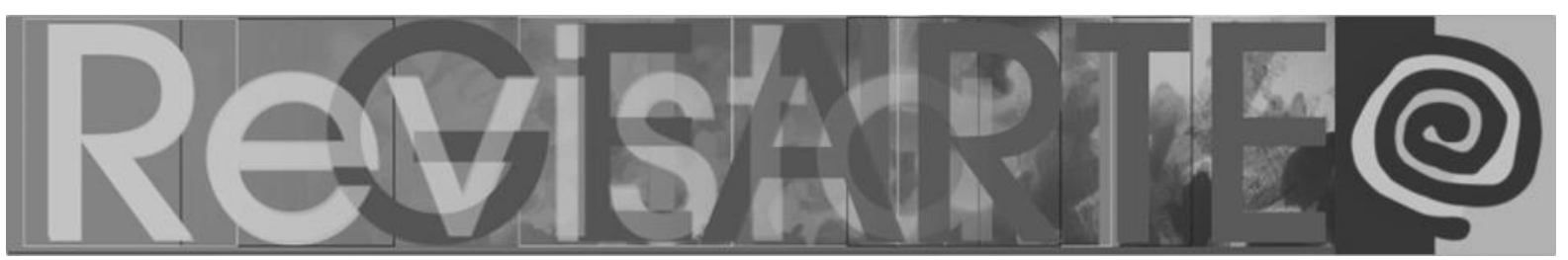

desenvolvidas, mas que despertassem outros canais de conhecimento (CARVALHO; TEODORO, 2017).

A proposta foi estruturada em três momentos: uma vivência corporal em grupo, a partir de estímulos rítmicos, percussivos e da memória; apresentação do solo Apartado - Sala 23 e uma roda de conversa sobre a experiência vivida. Pensando o corpo tanto como suporte expressivo e particular quanto como construção social impactado por representações culturais e relações de poder.

A corporalidade é o que há de mais íntimo e próprio da pessoa. Tão próprio e tão particular que é capaz de diferenciar uma pessoa dentre todas as outras. A humanidade é, aqui, a dimensão universal constituída por pessoas de corporalidade e, portanto, absolutamente inconfundíveis e incomparáveis. A pessoa é a expressão de sua corporalidade, sendo esta a mediação entre o particular mais íntimo do si-mesmo e a condição de coletividade da realidade em que a individualidade está contida como parte integrante e essencial. A corporalidade é tão pessoal que não poderia ser mais particular do que o si-mesmo, ao mesmo tempo em que estabelece relação com o outro e com o mundo a fim de afirmar sua particularidade a ponto da relação com o outro se transformar em caminho para o si-mesmo. [...] Enfim, a corporalidade é a identificação do "eu" consigo mesmo tão único e tão original que faz igualmente a pessoa ser única, incomparável e inigualável, ainda que necessite da coletividade como fator constitutivo da condição de pessoa. (OLIVEIRA, 2010, p. 178)

Figura 4 - Vivência corporal conduzida por Thalita Reis

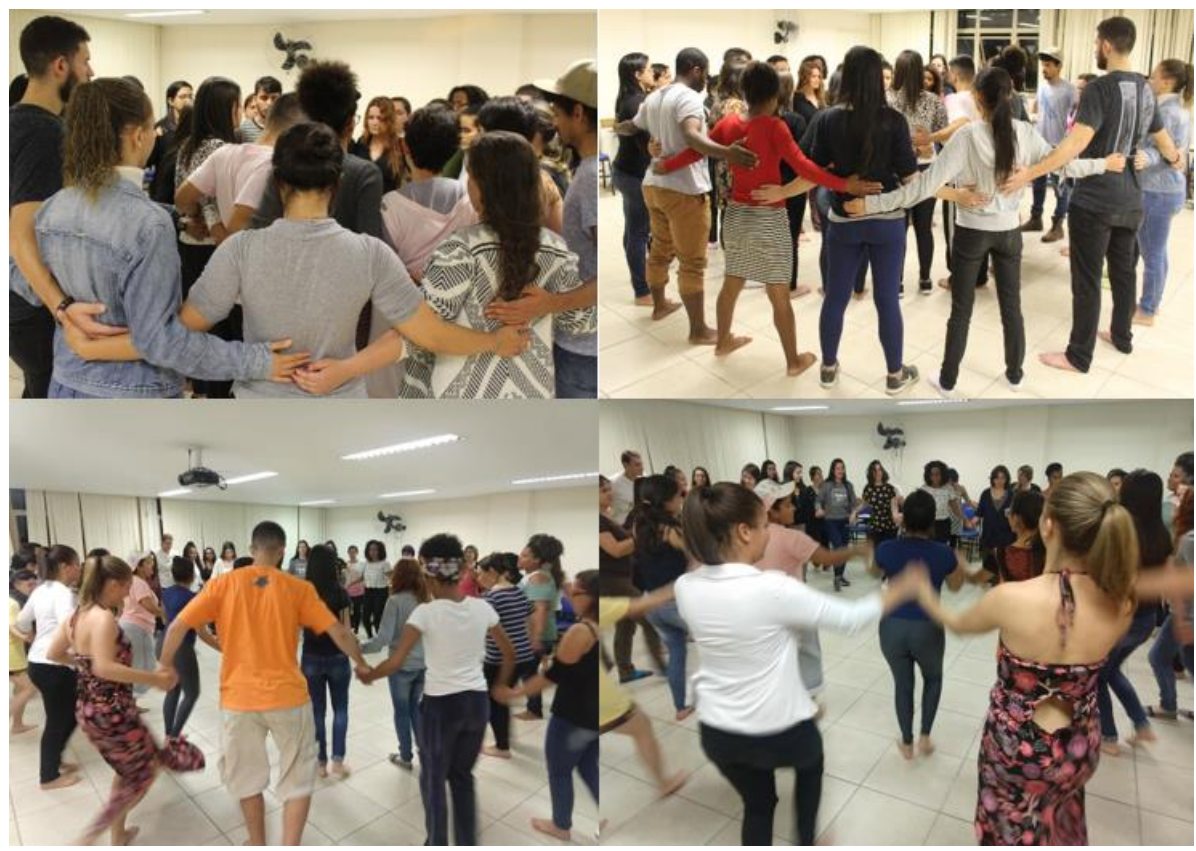

Fonte: Acervo do autor (2017).

CARVALHO, Francione Oliveira. A arte e a cultura afro-brasileira como descentramento sensorial na Pedagogia. 


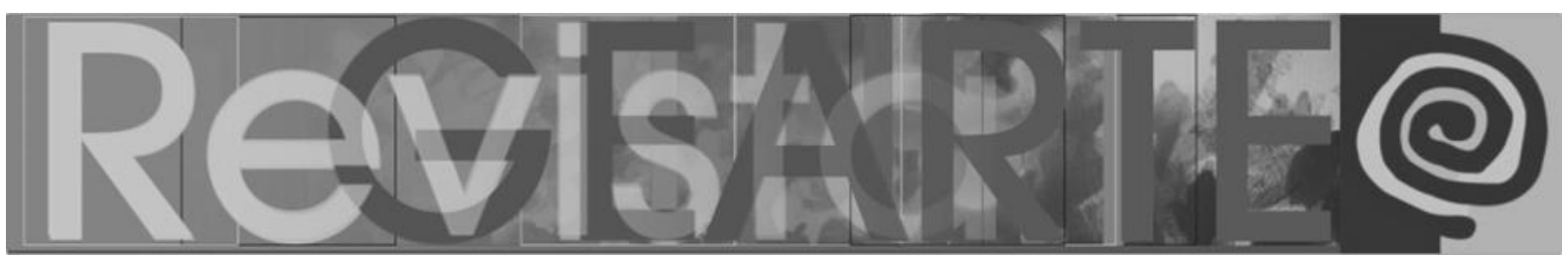

Na vivência corporal em grupo, a partir de estímulos rítmicos e percussivos africanos e afro-brasileiros, a turma foi estimulada a perceber o seu próprio corpo e a maneira como ele ocupa o espaço e se faz presente no grupo; em seguida, atividades em duplas e trios, até chegar a um único corpo coletivo. O resgate de brincadeiras, de jogos, de músicas e de histórias pessoais ao longo da experiência possibilitaram o diálogo com elementos fundamentais das culturas tradicionais da África e da cultura afro-brasileira, tais como a memória, a ancestralidade, a corporeidade, a circularidade, a ludicidade e a oralidade, pois o lúdico está presente em grande parte das tradições de matriz negra no Brasil, que buscam celebrar o movimento da vida. Friedmann (2006) afirma que, na nossa sociedade, "[...] há uma cultura de muitos brinquedos e de poucas brincadeiras, muita tecnologia e pouco artesanato, muita impessoalidade e pouco respeito à individualidade, muita solidão e pouca troca entre as pessoas" (FRIEDMANN, 2006, p. 123). Portanto, ao resgatar a ludicidade afro-brasileira, não estamos apenas celebrando a ancestralidade negra, mas também a infância. Algo importante para quem está inserido numa faculdade de educação.

No segundo momento, a turma teve a oportunidade de apreciar o solo de dança contemporânea Apartado - Sala 23, nome que faz referência ao número da sala onde as aulas aconteciam. O trabalho autobiográfico, iniciado em 2017, toca em memórias e no processo de construção da sua identidade enquanto artista, mulher e negra. Em seguida, sentados em círculo, após a apreciação do solo, além de questionarem questões específicas da linguagem da dança e da performance, a turma teceu vários comentários e impressões sobre a obra vista, entre eles a do desconforto em perceberem muitos pontos em comum entre o que foi mostrado na coreografia e a experiência vivida enquanto afrodescendentes. 


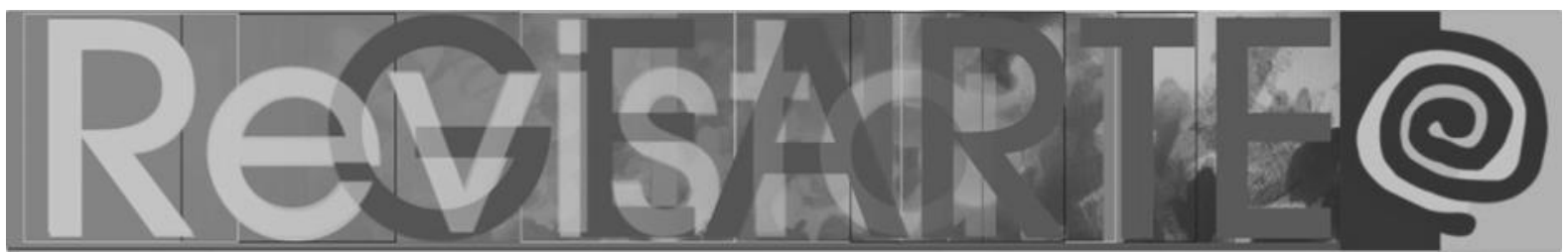

Figura 2 - Apresentação do trabalho coreográfico Apartado - Sala 23, de Thalita Reis
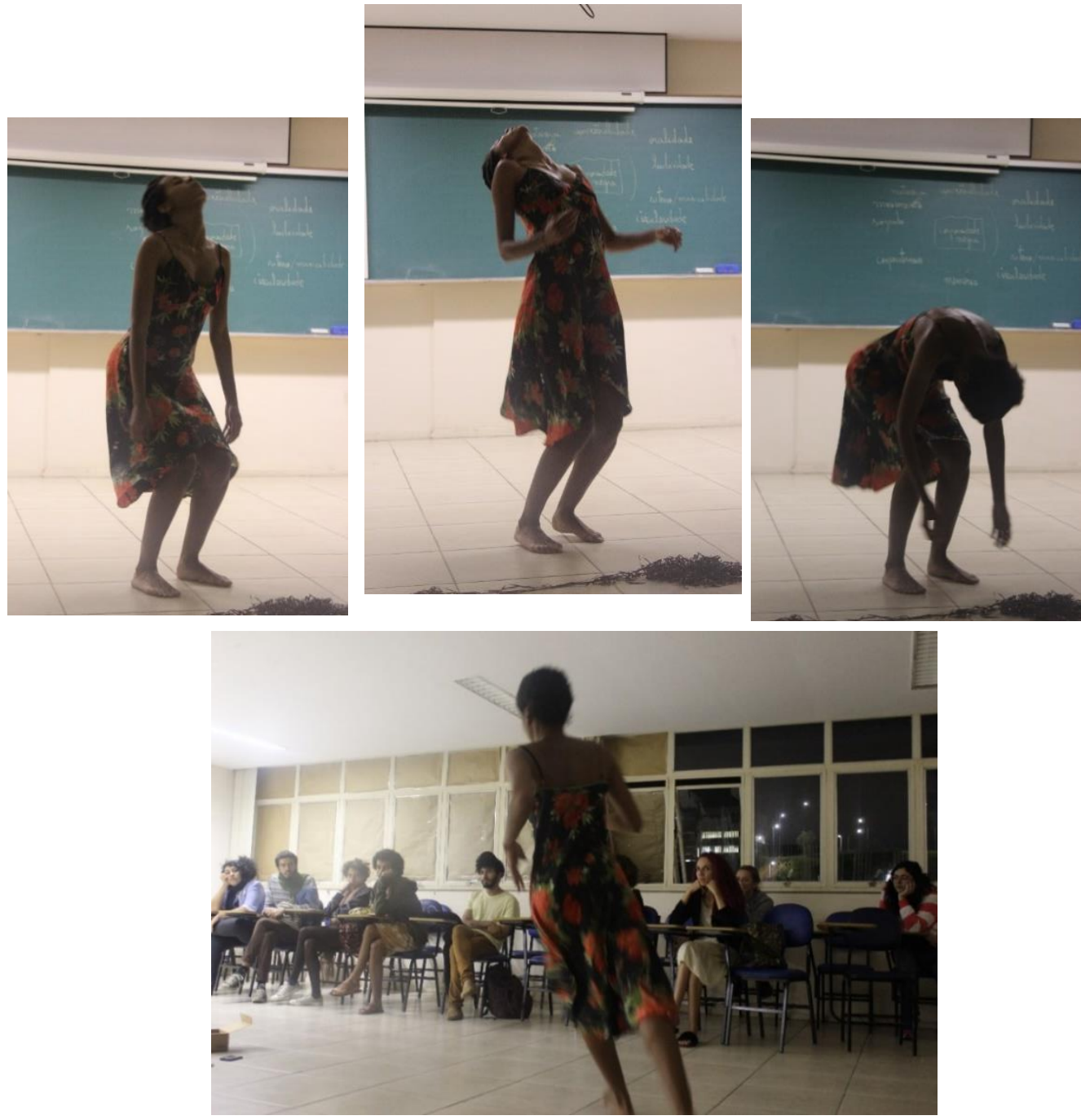

Fonte: Acervo do autor (2017).

\section{Processos Compartilhados de Criação}

$\mathrm{Na}$ reta final da disciplina, após terem passado por situações de aprendizagens diversas, os estudantes são estimulados a criar, em duplas e trios, imagens, sons, movimentos ou textos que expressem conceitos ou temáticas vivenciadas no semestre. O resultado estético dessa provocação vai depender do perfil dos matriculados naquele período, a ênfase dada pelo professor no curso e a nutrição estética (MARTINS; PICOSQUE, 2012) recebida pela turma. 


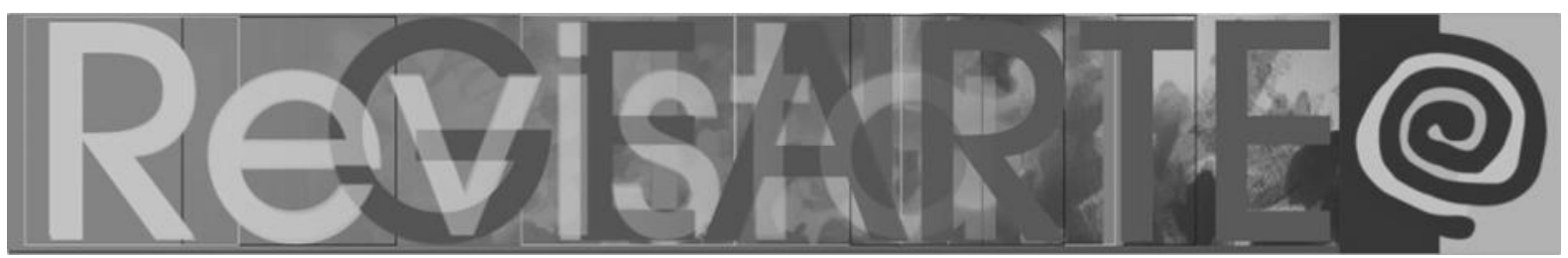

Uma constatação a partir dos trabalhos entregues pelos estudantes é a predominância das questões relativas à corporeidade, talvez pelo corpo ser uma dimensão física que extrapola o que é percebido. Ele carrega memórias, experiências e afetos que, num primeiro olhar, podem passar despercebidos. $O$ que é visível ou invisível no corpo diz muito a respeito das corporeidades. A maneira de lidarmos com nossos corpos é resultado, não apenas de percepções e narrativas individuais que os sujeitos criam sobre si mesmos, mas de representações, de construções do olhar e de dinâmicas sociais que incidem diretamente e, muitas vezes, violentamente sobre os corpos. Outra possível razão para o corpo centralizar a escolha temática da produção dos estudantes é sua a força na arte contemporânea e na criação dos artistas e das artistas afrodescendentes vistos no curso, tais como Rosana Paulino, Janaína Barros, Renata Felinto, Ayrson Heráclito, Jota Mombaça, Grada Kilomba e Paulo Nazareth.

As questões sobre a corporeidade negra, como as características físicas étnico-raciais, a incorporação de estereótipos e os imaginários racistas presentes desde os tempos coloniais e reforçados por teorias filosóficas e científicas excludentes, baseadas na inferiorizarão racial, são problematizadas nas visualidades afrodescendentes, porque são memórias e discursos que persistem e marcam os corpos dos artistas enquanto sujeitos negros. Pois, como diz Silva (2014), no Brasil, o racismo, a discriminação e o preconceito racial que incidem sobre negros ocorrem, não somente em decorrência de um pertencimento étnico expresso na vida, nos costumes, nas tradições e na história desse grupo, mas, também, "[...] pela conjugação desse pertencimento com a presença de sinais diacríticos, inscritos no corpo. Esses sinais remetem a uma ancestralidade negra e africana que se deseja ocultar e/ou negar" (SILVA, 2014, p. 31).

Nas tradições africanas e afro-brasileiras, o corpo integra o mundo natural e o mundo espiritual. A terra, a água, o fogo e o ar são fontes de vida que protegem contra energias negativas e aproximam os humanos da dimensão sagrada do invisível. A partir dessa compreensão holística sobre o mundo, Matheus Assunção, estudante da licenciatura em Artes Visuais, e Maré, da Pedagogia, criaram o vídeo 


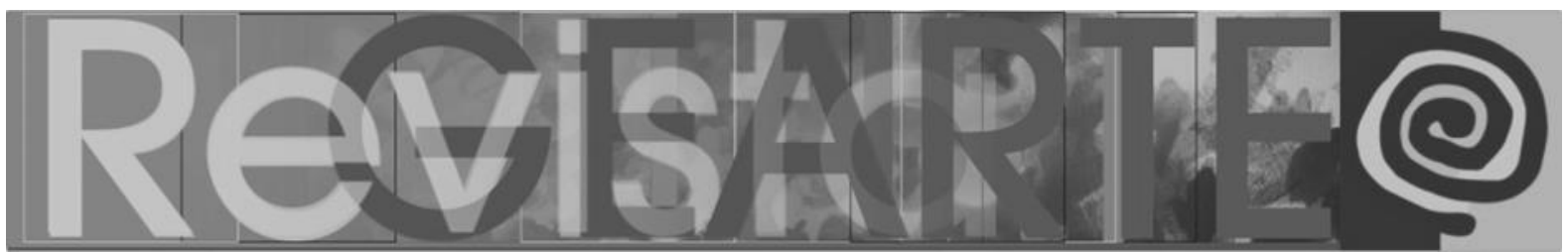

Elementos (2017) como trabalho final da disciplina. A obra foi apresentada e discutida em sala de aula e, no ano seguinte, incluída na exposição Preto ao Cubo (2018).

Figura 6 - Elementos, 2017, vídeo, 4`57”

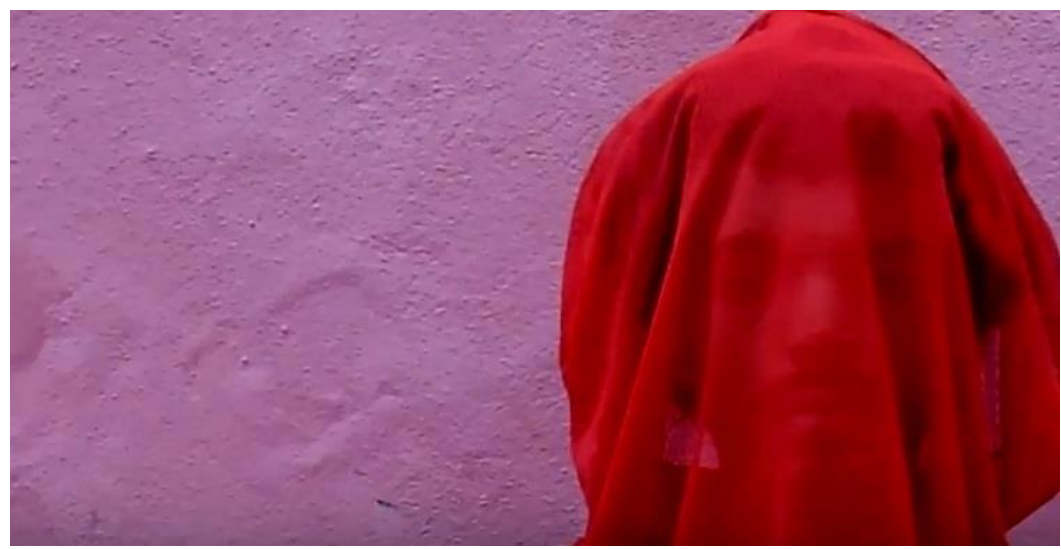

Fonte: Matheus Assunção e Maré (2017).

Figura 7 - Elementos, 2017, vídeo, 4`57”

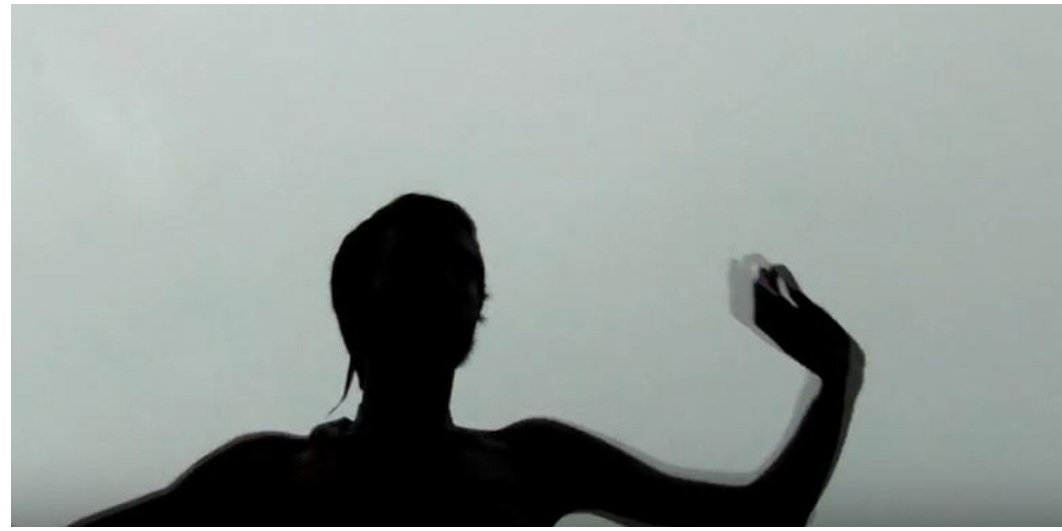

Fonte: Matheus Assunção e Maré (2017).

Figura 8 - Elementos, 2017, vídeo, 4`57”

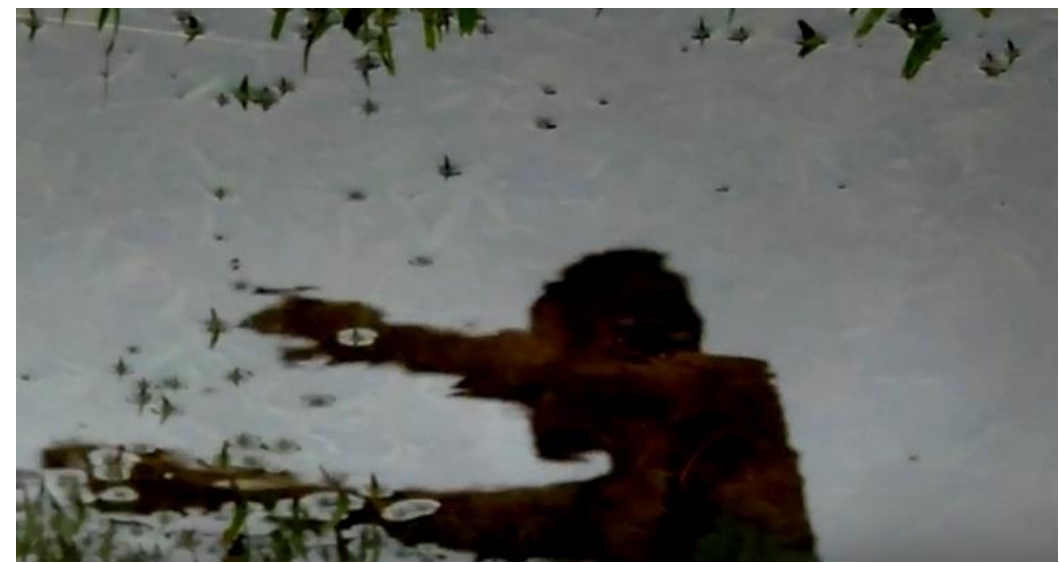

Fonte: Matheus Assunção e Maré (2017).

CARVALHO, Francione Oliveira. A arte e a cultura afro-brasileira como descentramento sensorial na Pedagogia. Revista GEARTE, Porto Alegre, v. 8, n. 2, p. 394-414, maio/ago. 2021.

Disponível em: http://seer.ufrgs.br/gearte 


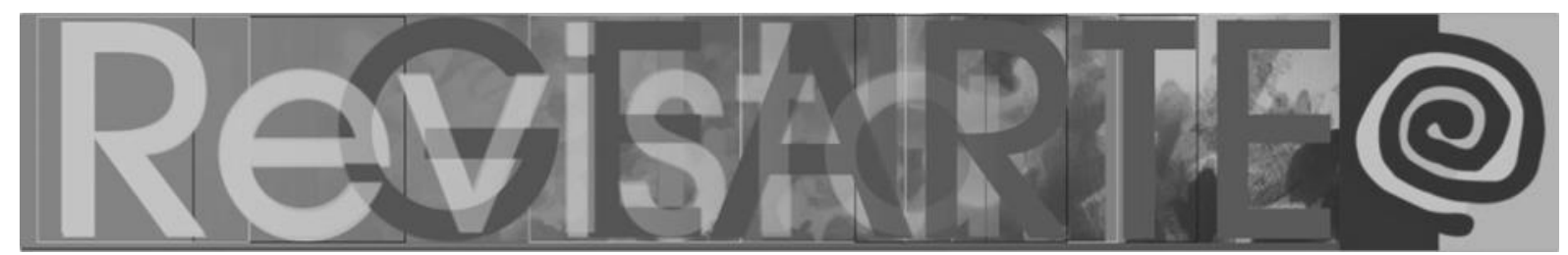

Figura 9 - Elementos, 2017, vídeo, 4`57”

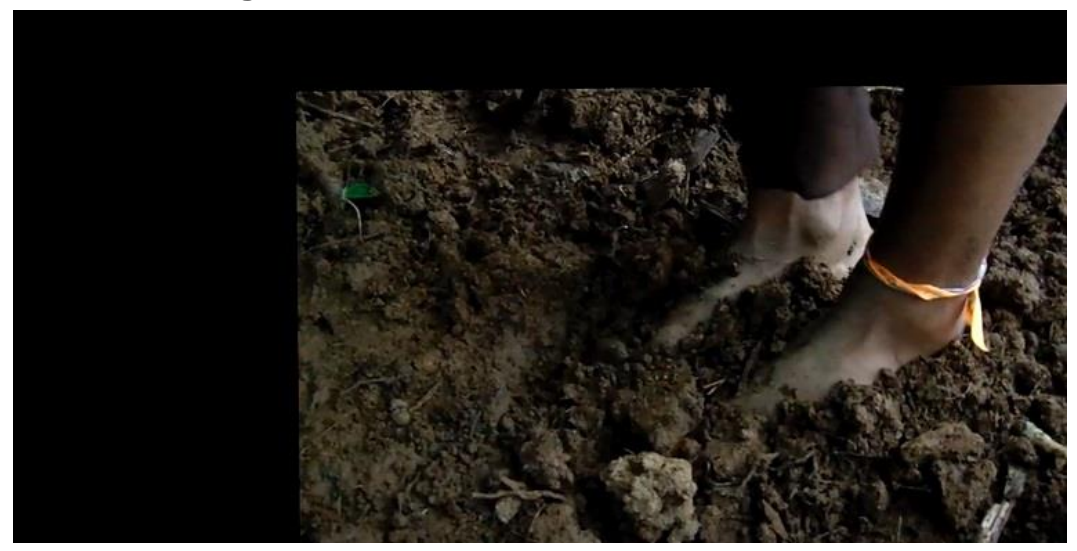

Fonte: Matheus Assunção e Maré (2017).

A qualidade estética que identificamos na obra Elementos, a partir da compreensão do conceito apresentado nesse texto, não será alcançada sempre por todos os estudantes, entretanto, isso não diminui a importância do trabalho gerado e apresentado em sala de aula. A criação artística é um trabalho a ser cultivado, para isso, os estudantes, principalmente os que não a exploram regularmente em suas graduações, que é o caso dos alunos da pedagogia, precisam ser estimulados, desafiados e alimentados na linguagem visual, para que possam vivenciar tanto processos de criação quanto de compreensão sensível e cognitiva da arte.

Muitas vezes, boas ideias não encontram formas eficientes que consigam dar conta de suas intenções. É nesse momento, com a mediação do professor, que novos saberes artísticos podem ser compreendidos e efetivados, pois como afirmam Ferraz e Fusari (2009), a aprendizagem de conhecimentos na área de arte acontece a partir de processos individuais e coletivos. "Logo, há necessidade de se conhecerem as particularidades de cada classe, cada grupo e cada aluno, o tempo de elaboração e resposta às situações de apresentadas" (FERRAZ; FUSARI, 2009, p. 141).

\section{Para Não Fechar Esse Texto}

O componente curricular arte, nos anos iniciais, deve estar à cargo do profissional formado em uma das licenciaturas específicas da área, contudo, nos 


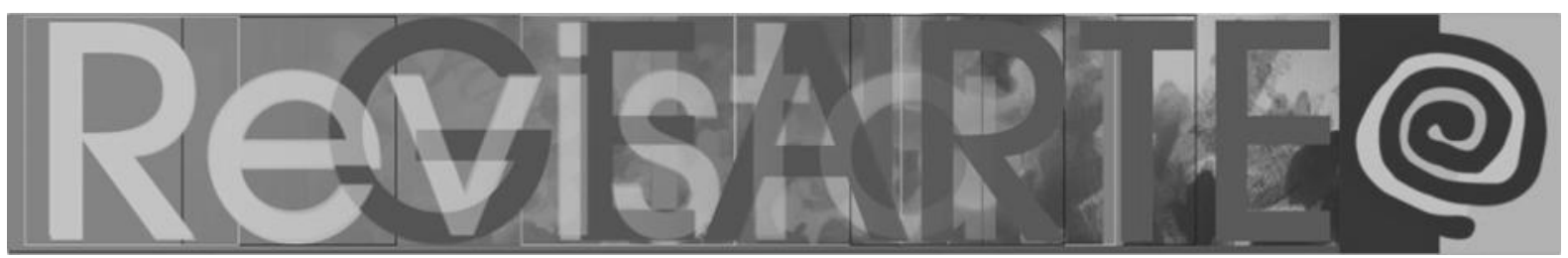

primeiros anos da escolarização, as linguagens artísticas estão presentes de diversas maneiras no cotidiano escolar e nas práticas pedagógicas. Portanto, é fundamental que os egressos da Pedagogia consigam transitar no mundo visualmente complexo e marcado por diferentes experiências culturais em que vivemos. Todavia, isso só será possível se, em suas formações, eles tenham a possibilidade de entrar em contato com a arte e a cultura a partir de experiências que envolvam a cognição, o afeto e a vida, porque como já apontou John Dewey (2010), é somente a partir desse envolvimento que podemos vivenciar experiências realmente significativas e estéticas.

A partir de diálogos interdisciplinares e da cultura afro-brasileira podemos ampliar os atravessamentos sensoriais e perceptivos aos quais os estudantes da pedagogia são expostos, provocando aquilo que Le Breton (2016) chama de descentramento sensorial. Uma maneira de desapegar-se das familiaridades perceptivas para recapturar outras maneiras de "[...] sentir a multidão dos mundos que se escoram no mundo" (LE BRETON, 2016, p. 19).

Se o indivíduo toma consciência de si através do sentir, cabe a formação de professores estimular e valorizar experiências sensoriais e perceptivas diversas. Nesse contexto, a cultura e a arte, por operarem com o simbólico, podem nos ajudar a dar sentido para o que nos atravessa. As pessoas habitam universos culturais e sensoriais diferentes, portanto, enquanto formadores de professores, precisamos ajudar os estudantes a desvelarem o sentido do que vivenciam. Afinal, só aquilo que faz sentido marca o campo da experiência.

Assim, ampliar o repertório de imagens e de referências dos alunos a partir de expedições culturais, conhecer melhor a cidade onde vivem e pensá-la como disparadora de processos educativos e artísticos, reconhecer a arte e a culturaafro brasileira como conhecimentos sensíveis que revelam diferentes experiências do mundo e experimentar a criação artística como produção de poéticas e sentidos são alguns dos objetivos que desejo alcançar ao longo da disciplina eletiva Arte e Cultura Afro-brasileira. Entretanto, a formação de um professor é algo inacabado 


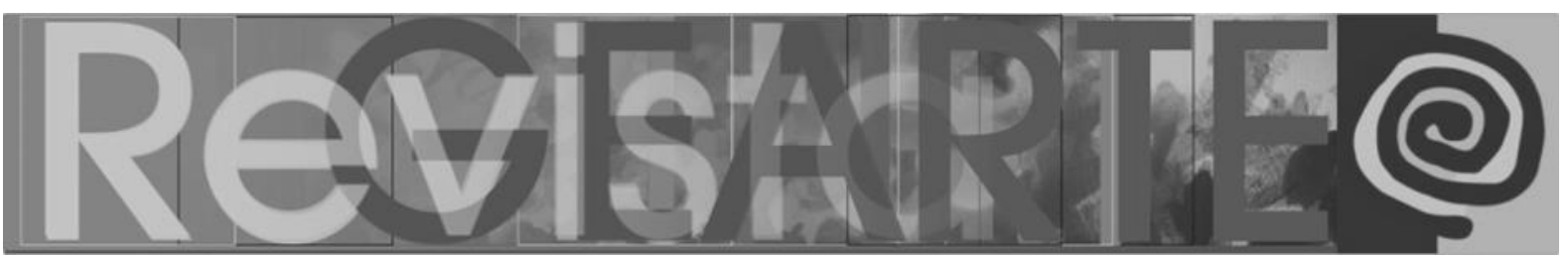

e que sempre dialogará com a incerteza. Incerteza do acerto, do erro, do término, da continuidade, do que se foi ou do que ficou neles, em mim, em nós.

\section{Referências}

BARBOSA, Ana Mae. Tópicos Utópicos. Belo Horizonte: C/Arte, 1998.

BRASIL. Lei no 10.639, de 09 de janeiro de 2003. Altera a Lei o 9.394, de 20 de dezembro de 1996. Brasília: Presidência da República, [2003]. Disponível em: http://www.planalto.gov.br/ccivil_ 03/Leis/2003/L10.639.htm. Acesso em: 18 mar. 2020.

BRASIL. Lei no 11.645 de 10 de março de 2008. Altera a Lei no 9.394, de 20 de dezembro de 1996. Brasília, DF: Presidência da República, [2008]. Disponível em: http://www.planalto.gov.br/ccivil_ 03/_Ato2007-2010/2008/Lei/L11645.htm. Acesso em: 18 mar. 2020.

CARVALHO, Francione Oliveira; TEODORO, Thalita de Cassia Reis. Apartado - Sala 23: Memórias, afetos e corporeidade negra na formação de professores. Revista COCAR, Belém, $\mathrm{n}$. 4, p. 73-92, 2017. Edição especial. Disponível em: <http://páginas.uepa.br/seer/index.php/cocar>. Acesso em: 18 mar. 2020.

DEWEY, John. Arte como experiência. São Paulo: Martins Fontes, 2010.

ELEMENTOS. [S. I.: Maré e Gogóia], 2017. 1 vídeo (5 min). Publicado pelo canal Assunção. Disponível em: <https://www.youtube.com/watch?v=K2RuTicgliM>. Acesso em: 18/03/2020.

FERRAZ, Maria Heloísa Correa de Toledo; FUSARI, Maria Felisminda de Rezende. Metodologia do Ensino de Arte: fundamentos e proposições. São Paulo: Cortez, 2009.

FRIEDMANN, Adriana. Brincar, crescer e aprender: o resgate do jogo infantil. São Paulo: Moderna, 1996.

LE BRETON, David. Antropologia dos sentidos. Petrópolis: Vozes, 2016.

MARTINS, Mirian Celeste; PICOSQUE, Gisa. Mediação cultural para andarilhos na cultura. São Paulo: Intermeios, 2012.

OLIVEIRA, Julvan Moreira de. Africanidades e educação: ancestralidade, identidade e oralidade no pensamento de Kabengele Munanga. São Paulo: Universidade de São Paulo, 2010. Tese (Doutorado em Educação) - Faculdade de Educação, Universidade de São Paulo, São Paulo, 2010. DOI 10.11606/T.48.2010.tde-20042010-153811. Disponível em: <https://www.teses.usp.br/ teses/disponiveis/48/48134/tde-20042010-153811/pt-br.php>. Acesso em: 18 mar. 2020.

SILVA, Joyce Gonçalves da. Corporeidade e Identidade, o corpo negro como espaço de significação. In: CONGRESSO INTERNACIONAL INTERDISCIPLINAR EM SOCIAIS E HUMANIDADES. 2014, Salvador. Anais [do] III Congresso Internacional Interdisciplinar em Sociais e Humanidades. Salvador: ANINTER/SH, 2014. ISSN 2316-266X, v. 17, n. 3, p. 263-275. Disponível em: <https://www.academia.edu/36341891/CORPOREIDADE_E_IDENTIDADE_O_CORPO_NE GRO_COMO_ESPA\%C3\%87O_DE_SIGNIFICA\%C3\%87\%C3\%830> Acesso em: 18 mar. 2020.

UNIVERSIDADE FEDERAL DE JUIZ DE FORA. Edital Programa Territórios Educativos da Graduação oํ 1, de 17 de junho de 2020. [Seleção de propostas de visitas técnicas, trabalhos de campo, viagens formativas no âmbito dos cursos de graduação no programa Territórios Educativos da Graduação]. Juiz de Fora: Pró-reitoria de Graduação, 2020. 


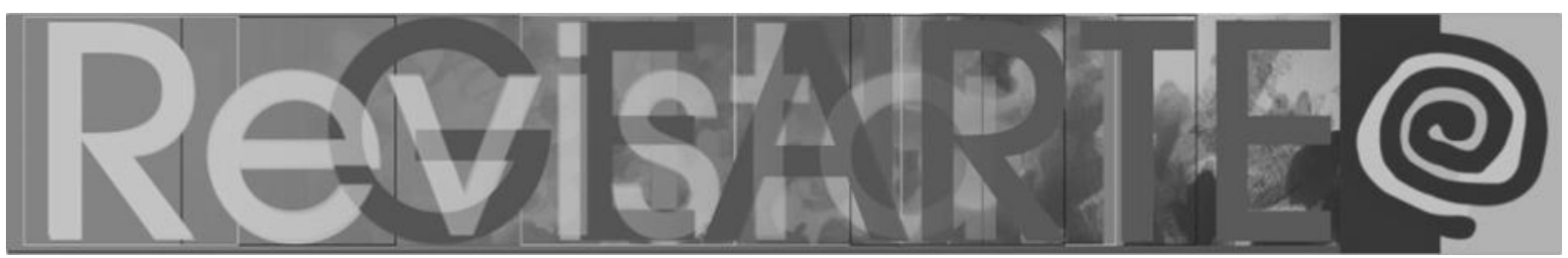

\section{Francione Oliveira Carvalho}

Professor nas Licenciaturas de Artes Visuais e Pedagogia da Universidade Federal de Juiz de Fora/MG. Graduação em Artes Cênicas e em Artes Visuais. Mestre e Doutor em Educação, Arte e História da cultura pela Universidade Presbiteriana Mackenzie. Pós-doutorado em História na Universidade de São Paulo. Líder do MIRADA - Grupo de Estudos e pesquisa sobre Visualidades, Interculturalidade e Formação Docente, UFJF.

ORCID: http://orcid.org/0000-0001-7511-5708

E-mail: francioneoliveiracarvalho@gmail.com

Currículo: http://lattes.cnpq.br/6262224578426097

Recebido em 22 de fevereiro de 2021 Aceito em 30 de abril de 2021 